\title{
Uji Daya Hambat Sabun Cair Cuci Tangan pada Restoran Waralaba di Kota Padang Terhadap Pertumbuhan Bakteri Escherichia coli dan Staphylococcus aureus Secara In Vitro
}

\author{
Anisha Fazlisia ${ }^{1}$, Elizabeth Bahar ${ }^{2}$, Yulistini ${ }^{2}$
}

\begin{abstract}
Abstrak
Sabun cair cuci tangan terbukti dapat menghambat pertumbuhan bakteri Escherichia coli dan Staphylococcus aureus. Sebagian besar restoran waralaba di Kota Padang menyediakan sabun cair cuci tangan yang telah diencerkan. Proses pengenceran mengubah kemampuan sabun dalam menghambat pertumbuhan bakteri. Penelitian bertujuan untuk menguji daya hambat sabun cair cuci tangan pada restoran waralaba di Kota Padang terhadap pertumbuhan E. coli dan S. aureus. Sampel diambil dari empat restoran waralaba dan diuji dengan metode difusi. Hasil penelitian menunjukkan bahwa keempat sabun dapat menghambat pertumbuhan $S$. aureus namun hanya sebagian yang memiliki daya hambat terhadap E. coli. Median daya hambat pertumbuhan E. coli dan S. aureus pada setiap periode yaitu $0,7.4,7.3$ dan $0,26.1,23$.3. Nilai maksimum daya hambat pertumbuhan $E$.coli dalam tiga periode yaitu 19.5, 35.4, 27.1 dan 20.7, 40.2, 36.6 untukS. aureus. Daya hambat minimum terhadap kedua bakteri adalah 0.00 . Hal tersebut dapat dipengaruhi komposisi dan konsentrasi antiseptik, antibakteri, pH sabun, pengenceran dan struktur dinding sel bakteri. Disimpulkan bahwa sabun cair cuci tangan yang diuji memiliki kemampuan lebih besar dalam menghambat pertumbuhan S.aureus daripada E.coli.
\end{abstract}

Kata kunci: sabun cair cuci tangan, restoran, pengenceran, uji daya hambat, pertumbuhan bakteri

\section{Abstract}

Liquid hand soaps proved to inhibit Escherichia coli and Staphylococcus aureus bacterial growth. In Padang, most of Restaurants provide diluted liquid hand soaps. Research found dilution changed soap ability to inhibit bacterial growth. The purpose of this study was to examine the ability of Padang City Restaurants' liquid hand soaps to inhibit E. coli and S. aureus bacterial growth. The samples were taken from four restaurants and examined by using diffusion method. The results showed all of them could inhibit $S$. aureus but only a half inhibited Escherichia coli bacterial growth. Median for E. coli and S. aureus bacterial inhibition growth for each period were 0, 7.4, 7.3 and 0, 26.1, 23.3. Maximum inhibition value for E. coli growth in the first, second, and third periods were 19.5, 35.4, 27.1 and 20.7, 40.2, and 36.6 for $S$. aureus. In addition, minimum inhibition in both bacteria were 0.00 . It could be influenced by soap antiseptic and antibacterial composition and concentration, $\mathrm{pH}$, dilution, and structure of bacterial cell wall. In conclusion, the liquid hand soaps has greater ability to inhibit S. aureus than E. coli.

Keywords: liquid hand soaps, restaurant, dilution, inhibitory test, bacterial growth

Affiliasi penulis : 1. Fakultas Kedokteran Universitas Andalas Padang), 2. Bagian Mikrobiologi FK UNAND, 3. Mikrobiologi FK UNAND

Korespondensi : Anisha Fazlisia, email:

anishafazlisia@rocketmail.com, Telp: 085274856585

\section{PENDAHULUAN}

Sabun adalah kumpulan senyawa yang terdiri dari satu jenis asam amino atau lebih atau ekuivalennya dan alkali. ${ }^{1}$ Sabun dihasilkan dari reaksi 
antara minyak hewani, nabati atau lemak yang direbus bersama dengan sodium hidroksida. Sabun tidak hanya digunakan untuk menjaga kebersihan badan tetapi juga untuk kebersihan tangan. Mencuci tangan dengan sabun lebih efektif dan efisien jika dibandingkan dengan hanya menggunakan air. ${ }^{2}$ Penelitian yang dilakukan oleh Mwambate dan Lyombe (2011) dengan cara membiakkan bakteri Pseudomonas aeroginosa, Staphylococcus aureus dan Escherichia coli di dalam cawan petri yang berisi sabun cair cuci tangan menunjukkan bahwa sabun cair cuci tangan memiliki daya hambat terhadap bakteri-bakteri tersebut. ${ }^{3}$ Penelitian lain yang dilakukan oleh Burton dkk pada tahun 2010 membuktikan bahwa jumlah bakteri pada telapak tangan yang dicuci menggunakan sabun lebih sedikit dibandingkan dengan jumlah bakteri yang ditemukan pada tangan yang dicuci tanpa sabun. ${ }^{4}$

Sabun cair cuci tangan terkandung zat-zat yang bersifat bakterisid dan bakteriostatik. ${ }^{5}$ Zat-zat tersebut seperti alkohol dan antibakteri. Selain itu, derajat keasaman $(\mathrm{pH})$ sabun cair cuci tangan juga berperan dalam menghambat pertumbuhan dan membunuh bakteri. ${ }^{6}$

Pemerintah mengharuskan setiap restoran waralaba untuk menyediakan tempat cuci tangan beserta sabun sebagai upaya untuk menurunkan angka penyakit infeksi saluran pencernaan. ${ }^{7}$ Meningkatnya angka penyakit infeksi saluran pencernaan saat ini tidak hanya disebabkan oleh bakteri yang berasal dari konsumen sendiri tetapi juga dari para pengolah makanan atau food-handler. ${ }^{8}$

Bakteri Escherichia coli strain tertentu merupakan bakteri Gram negatif yang banyak menyebabkan penyakit infeksi saluran pencernaan selain Vibrio cholera dan rotavirus. Bakteri ini bertransmisi melalui jalur fekal-oral akibat rendahnya kualitas kebersihan individu (konsumen). Selain bakteri Gram negatif, toksin bakteri Gram positif seperti $S$. aureus yang bersifat termostabil juga dapat menyebabkan penyakit infeksi. ${ }^{9}$ Toksin $S$. aureus berperan besar dalam meningkatnya wabah infeksi saluran cerna akibat keracunan makanan atau foodpoisoning disease. Toksin tersebut dihasilkan oleh bakteri $S$. aureus yang masuk dan berkembang di dalam makanan akibat dari proses pengolahan yang tidak bersih oleh food-handler. $^{8}$

Sabun cair cuci tangan disediakan diberbagai fasilitas umum seperti restoran waralaba. Sabun cair cuci tangan yang disediakan di restoran waralaba di Kota Padang sudah mengalami proses pengenceran dengan jumlah yang berbeda-beda. Pengenceran sabun cair cuci tangan mengubah $\mathrm{pH}$, konsentrasi antiseptik seperti alkohol, dan antibakteri sebagai kandungan tambahan yang terlarut di dalam sabun sehingga akan mempengaruhi kemampuan sabun dalam menghambat dan membunuh bakteri. ${ }^{2}$

Berdasarkan uraian di atas, penelitian ini bertujuan melakukan uji sensitivitas untuk mengetahui daya hambat sabun cair cuci tangan yang tersedia pada restoran waralaba di Kota Padang terhadap pertumbuhan bakteri Escherichia coli dan Staphylococcus aureus secara in vitro.

\section{METODE}

Penelitian jenis eksperimental dengan Post test Only with Control Group Design. Penelitian dilakukan di Laboratorium Mikrobiologi Fakultas Kedokteran Universitas Andalas dari bulan September sampai dengan November 2013. Populasi dari sampel yang digunakan dalam penelitian adalah sabun cair cuci tangan pada restoran waralaba di Kota Padang. Sampel penelitian yaitu sabun cair cuci tangan yang telah mengalami pengenceran dan berasal dari restoran waralaba di Kota Padang dengan mekanisme pengonsumsian makanan langsung menggunakan tangan. Besar sampel yang digunakan sebanyak empat jenis sabun cair cuci tangan.

Variabel independen atau bebas yaitu empat sabun cair cuci tangan dari cabang-cabang restoran waralaba di Kota Padang. Variabel dependen atau terikat yaitu pertumbuhan bakteri Escherichia coli dan Staphylococcus aureus.

Pengujian dilakukan dengan metode difusi. Cakram dibuat dengan merekatkan tiga lapis kertas saring yang kemudian dilubangkan dengan pelubang kertas berukuran $4 \mathrm{~mm}$. Selanjutnya, disusun dalam cawan petri dan disterilkan dengan autoklaf. Setelah dingin, cakram dibagi menjadi tiga kelompok. Kelompok pertama dan kedua terlebih dahulu 
dicelupkan ke dalam sabun sebelum dimasukkan ke dalam cawan petri yang telah berisi agar. Kelompok pertama, dicelupkan ke dalam sabun cair cuci tangan yang berasal dari restoran waralaba di Kota Padang dan kelompok kedus ke dalam sabun cair cuci tangan yang digunakan sebagai kontrol.

Data yang diperoleh dari penelitian dicatat pada tabel yang kemudian disajikan dalam bentuk grafik dan diolah secara statistik deskriptif untuk menemukan nilai median, maksimum, dan minimum.

HASIL

Tabel 1. Uji Daya Hambat Sabun Cair Cuci Tangan Terhadap Pertumbuhan Bakteri Escherichia coli dan Staphylococcus aureus

\begin{tabular}{|c|c|c|c|c|}
\hline \multirow[t]{2}{*}{ Bakteri } & \multirow[t]{2}{*}{ Sabun } & \multicolumn{3}{|c|}{$\begin{array}{c}\text { Rata-rata } \varnothing \text { Daya Hambat } \\
\text { terhadap Pertumbuhan } \\
\text { Kuman Per Periode } \\
\text { Pengambilan Sampel (mm) }\end{array}$} \\
\hline & & I & II & III \\
\hline \multirow{5}{*}{$\begin{array}{l}\text { Escherichia } \\
\text { coli }\end{array}$} & $A$ & - & - & - \\
\hline & $B$ & 19.5 & 20.9 & 15.9 \\
\hline & $\mathrm{C}$ & - & 35.4 & 27.1 \\
\hline & $\mathrm{D}$ & - & - & - \\
\hline & $E$ & 7.2 & 7.4 & 7.3 \\
\hline \multirow{5}{*}{$\begin{array}{l}\text { 2. Staphylococcus } \\
\text { aureus }\end{array}$} & A & - & 26.1 & 23.3 \\
\hline & $B$ & 20.7 & 34.6 & 30.1 \\
\hline & C & - & 40.2 & 36.6 \\
\hline & $\mathrm{D}$ & - & 18.1 & 11.2 \\
\hline & $E$ & 6.2 & 9.2 & 7.3 \\
\hline
\end{tabular}

Keterangan :

$$
\begin{array}{ll}
\mathrm{A} & =\text { sabun yang berasal dari restoran } \mathrm{T} \\
\mathrm{B} & =\text { sabun yang berasal dari restotan } \mathrm{K} \\
\mathrm{C} & =\text { sabun yang berasal dari restoran } \mathrm{M} \\
\mathrm{D} & =\text { sabun yang berasal dari restoran } \mathrm{CF} \\
\mathrm{E} & =\text { kontrol }
\end{array}
$$

Pada tabel 1 diatas terlihat bahwa bakteri Escherichia coli hanya sensitif terhadap sabun dari restoran B dan C sedangkan bakteri Staphylococcus aureus sensitif terhadap keempat sabun cair cuci tangan.

Gambar 1 menunjukkan bahwa pada pengujian periode pertama sabun $A, C$, dan $D$ tidak memiliki daya hambat terhadap pertumbuhan $E$. coli. Pada periode berikutnya, sabun $\mathrm{C}$ memperlihatkan adanya daya hambat terhadap pertumbuhan bakteri sedangkan sabun $A$ dan $D$ tetap tidak menunjukkan hal tersebut sampai dengan pengujian periode ketiga. Diameter zona bebas pertumbuhan bakteri terbesar pada periode pertama terdapat di sekitar sabun B sedangkan periode kedua dan ketiga terukur disekitar sabun $\mathrm{C}$.

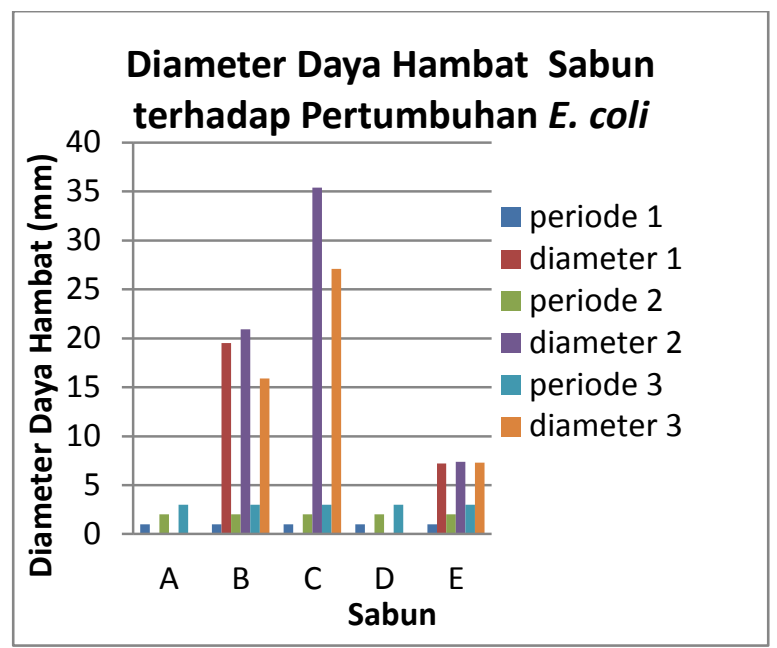

Gambar 1. Rata-rata Daya Hambat Sabun Cair Cuci Tangan Terhadap Pertumbuhan Bakteri Escherichia coli

Berdasarkan Gambar 2 dapat diamati bahwa sabun A, C, dan D pada periode pertama tidak menunjukkan adanya daya hambat terhadap pertumbuhan $S$. aureus. Ketiga sabun tersebut baru memperlihatkan zona bebas pertumbuhan bakteri pada pengujian periode kedua dan ketiga. Diameter zona bebas pertumbuhan terbesar pada periode pertama dimiliki sabun $B$ sedangkan periode kedua dan ketiga dibentuk oleh sabun $\mathrm{C}$.

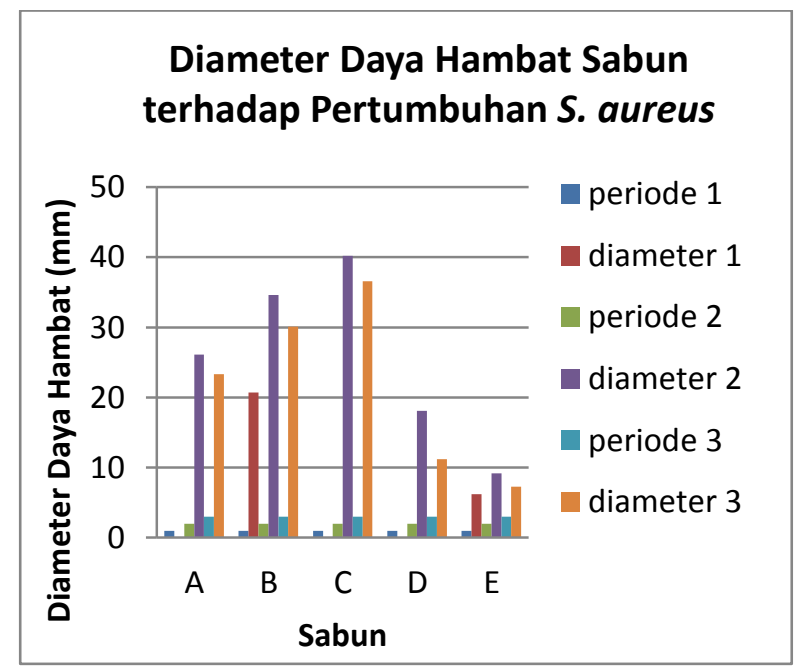

Gambar 2. Rata-rata Daya Hambat Sabun Cair Cuci Tangan Terhadap Pertumbuhan Bakteri Staphylococcus aureus 
Hasil pengolahan data menggunakan statistik deskriptif terlihat median, nilai maksimum, dan minimum untuk setiap periode. Pada daya hambat terhadap pertumbuhan $E$. coli didapatkan median untuk periode pertama, kedua dan ketiga sebesar 0 , 7.4 , dan 7.3 serta nilai maksimum secara berturut-turut adalah 19.5, 35.4, dan 27.1. Sementara itu, median daya hambat pertumbuhan $S$. aureus pada periode pertama, kedua dan ketiga yaitu $0,26.1$, dan 23.3 dengan nilai maksimum untuk masing-masing periode secara berurutan mulai dari periode pertama sampai dengan ketiga yaitu sebesar 20.7, 40.2 dan 36.6. Nilai minimum untuk daya hambat kedua bakteri adalah 0.00 .

\section{PEMBAHASAN}

Sabun cair cuci tangan merupakan salah satu sarana kebersihan yang saat ini banyak digunakan. Penggunaan sabun cair cuci tangan semakin meningkat karena dapat menghambat dan membunuh bakteri. $^{10}$

Hasil penelitian ini menunjukkan bahwa keempat sabun cair cuci tangan yang diuji mampu menghambat pertumbuhan bakteri $S$. aureus namun hanya sebagian yang dapat menghambat pertumbuhan bakteri E. coli. Hal ini bertolak belakang dengan hasil penelitian yang dilakukan oleh Mwambate dan Lyombe (2011) bahwa sabun cair cuci tangan dapat menghambat pertumbuhan bakteri, baik E. coli maupun S. aureus. ${ }^{3} \mathrm{Hal}$ ini dapat disebabkan karena adanya perbedaan kandungan dan kekentalan (konsentrasi) sabun yang digunakan sebagai sampel dalam penelitian. Lyombe dan Mwambate (2011) menguji daya hambat sabun cair cuci tangan yang dijual di pasaran tanpa pengenceran sedangkan pada penelitian ini sabun berasal dari restoran waralaba di Kota Padang yang sudah terlebih dahulu mengalami pengenceran.

Kandungan menjadi salah satu faktor yang menentukan daya hambat sabun. ${ }^{2}$ Sabun yang mengandung antiseptik dapat menghambat dan membunuh bakteri ${ }^{11}$ tetapi kemampuan sabun akan lebih besar jika memiliki kandungan tambahan seperti antibakteri. Hal ini dikarenakan kerja atau aktivitas antiseptik bersifat sementara dan tidak cukup efektif untuk menyebabkan kematian sel bakteri (sublethal) sehingga memungkinkan bakteri untuk tumbuh kembali. Penambahan antibakteri sebagai salah satu kandungan sabun akan memberikan efek yang lebih baik dan permanen dalam menghambat pertumbuhan dan membunuh bakteri. ${ }^{11}$

Kemampuan sabun cair cuci tangan dalam menghambat pertumbuhan bakteri turut dipengaruhi oleh konsentrasi antiseptik atau antibakteri yang terdapat di dalam sabun. Peningkatan konsentrasi akan meningkatkan kemampuan dalam menghambat pertumbuhan bakteri dan demikian sebaliknya. ${ }^{2}$

Derajat keasaman $(\mathrm{pH})$ juga berperan dalam menghambat pertumbuhan bakteri $E$. coli dan $S$. aureus. $\mathrm{pH}$ optimal pertumbuhan bakteri-bakteri ini berkisar antara 7.2-7.6. ${ }^{12}$ Sabun dengan $\mathrm{pH}$ lebih rendah atau tinggi dari angka tersebut mampu menghambat pertumbuhan $E$. coli dan $S$. aureus dibanding sabun dengan $\mathrm{pH}$ sama atau mendekati $\mathrm{pH}$ optimal. $^{13}$

Sabun cair cuci tangan yang diuji dalam penelitian ini adalah sabun yang telah mengalami pengenceran oleh pihak restoran. Hasil pengujian menunjukkan bahwa daya hambat sabun cair cuci tangan pada periode pertama jauh lebih rendah daripada periode kedua dan ketiga.

Berdasarkan pengamatan, sabun yang diambil pada periode pertama mempunyai konsistensi yang lebih encer daripada periode kedua dan ketiga sehingga dapat menjadi alasan mengapa daya hambat pada periode pertama tidak sebaik kedua dan ketiga. Peristiwa ini sesuai dengan hasil penelitian yang dilakukan Oranusi, et al (2013) dengan mengencerkan sejumlah sabun sesuai dengan jumlah pengenceran yang biasa dilakukan di restoran dan menunjukkan bahwa peningkatan jumlah pengenceran berbanding lurus dengan peningkatan jumlah bakteri yang tumbuh dan berbanding terbalik dengan kemampuan sabun cair cuci tangan untuk menghambat pertumbuhan bakteri. ${ }^{2}$

Pengenceran sabun juga akan mempengaruhi $\mathrm{pH}$ sabun cair cuci tangan. $\mathrm{pH}$ sabun yang awalnya asam atau basa dapat berubah menjadi netral. $\mathrm{pH}$ netral merupakan faktor lingkungan yang optimal bagi pertumbuhan bakteri sehingga menurunkan 
kemampuan bakterisid dan bakteriostatik sabun. ${ }^{13}$

Berdasarkan hasil penelitian terdapat sabun yang tidak mempunyai kemampuan dalam menghambat pertumbuhan bakteri saat pengujian periode pertama namun mampu membentuk zona bebas pertumbuhan bakteri yang sangat besar pada periode kedua. Proses pengenceran yang berlebihan, peristiwa di atas mungkin terjadi karena pada periode pertama pihak restoran hanya menambahkan air ke dalam tabung atau tempat sabun guna menambah jumlah sabun sehingga konsentrasi sabun yang dijadikan sampel pada periode pertama jauh lebih rendah dari pada periode selanjutnya. Kemungkinan penggantian sabun oleh pihak restoran pada periode kedua dengan sabun yang memiliki kandungan antiseptik dan atau antibakteri yang lebih baik daripada sabun periode pertama. Di samping itu, kesalahan teknis dalam melakukan pengujian juga dapat menyebabkan hal ini terjadi.

Penelitian ini juga menunjukkan bahwa sabun dari restoran waralaba yang telah mengalami pengenceran memiliki daya hambat yang lebih baik terhadap $S$. aureus daripada sabun kontrol yang tidak mengalami pengenceran. Hal ini disebabkan karena sabun kontrol lebih kental dan padat sehingga zat-zat didalam sabun tidak efektif berdifusi ke dalam cakram dan memerlukan waktu yang lebih lama jika dibandingkan sabun yang mengalami pengenceran. ${ }^{14}$

Selanjutnya, pada penelitian ini terlihat perbedaan kemampuan sabun cair cuci tangan dalam menghambat pertumbuhan bakteri $E$. coli dan $S$. aureus. Perbedaan ini dipengaruhi struktur dinding sel bakteri. Escherichia coli merupakan bakteri Gram negatif yang memiliki struktur dinding sel yang lebih kompleks dibanding bakteri Gram Positif seperti Staphylococcus aureus. Pada bagian luar membran sitoplasma terdapat periplasmik yang mengandung peptidoglikan yang lebih tipis dibanding $S$. aureus dan jarang berikatan antara unsur-unsurnya. ${ }^{15} \mathrm{Hal}$ ini membantu $E$. coli menghindari aktivitas dari bahan aktif sabun yaitu asam lemak. ${ }^{16}$

Braun's lipoprotein yang berikatan dengan peptidoglikan memperkuat ikatan peptidoglikan dengan membran luar. LPS (lipopolisakarida) pada membran luar bertugas untuk menolak atau mendorong keluar zat hidrofobik dan protein porin mengatur permiabilitas sel yang hanya meloloskan zat yang bersifat hidrofilik sehingga antiseptik yang bersifat hidrofobik tidak dapat dengan mudah memasuki sel. $^{15}$

\section{KESIMPULAN}

Berdasarkan penelitian yang telah dilakukan mengenai uji daya hambat sabun cair cuci tangan pada restoran waralaba di Kota Padang terhadap pertumbuhan bakteri Escherichia coli dan Staphylococcus aureus secara in vitro, didapat kesimpulan sebagai berikut:

1. Dua dari empat sampel sabun cair cuci tangan yang berasal dari restoran waralaba di Kota Padang dapat menghambat pertumbuhan bakteri Escherichia coli dan salah satunya menunjukkan nilai ekstrem pada pengujian periode kedua.

2. Semua sampel sabun cair cuci tangan yang berasal dari restoran waralaba di Kota Padang dapat menghambat pertumbuhan bakteri Staphylococcus aureus dan satu diantara keempat sampel tersebut menunjukkan nilai ekstrem pada pengujian periode kedua.

\section{UCAPAN TERIMA KASIH}

Penulis mengucapkan terima kasih kepada dr. Aziz Djamal, M.Sc DTM\&H, Sp.MK dan seluruh staff Laboratorium Mikrobiologi FK UNAND yang telah membantu terlaksananya penelitian ini.

\section{DAFTAR PUSTAKA}

1. Dorland WA. Dorland's illustrated medical dictionary. $31^{\text {th }}$ ed. Singapore: Elsevier; 2007.

2. Oranusi US, Akanade VA, Dahunsi SO. Assessment of microbial quality and antibacterial activity of commonly used hand washes. Journal of Biological and Chemical Research. 2013;30(2):570-80.

3. Mwambete KD, Lyombe F. Antimicrobial activity of medicated soaps commonly used by dar es salaam residents in Tanzania. Indian Journal of Pharmaceutical Sciences. 2011; 73(1): 92-8.

4. Burton, Maxine, Cobb, Emma, Donachie, Petter., Judah, Gaby, Curtis, Val. and Schmidt, Wolf-Peter. The effect of 
handwashing with water or soap on bacterial contamination of hands. Int. J. Environ. Res. Public Health. 2011; (8):97-104.

5. Selvamohan T, Sandhya, V. Studies on bactericidal activity of different soaps againstbacterial strains. Journal of Microbiology and Biotechnology Research. 2012; 2(5):646-50.

6. Presscott, Lansing M, Harley, John P, Klein, Donald A. Microbiology. Edisi ke-5. United State of America: McGraw-Hill; 2003.

7. Kementerian Kesehatan Republik Indonesia. Higiene sanitasi jasaboga. Peraturan Menteri Kesehatan Republik Indonesia Nomor 1096/Menkes/Per/Vi/201: 2011 [diunduh 9 Desember 2012]. Tersedia dari: URL: HYPERLINK http://www.hukor.depkes.go. id/up prod permenkes/PMK\%20No.\%20109 6\%20ttg\%20Higiene\%20Sanitasi\%20Jasabo ga.pdf.

8. Loir YL, Baron F, Gautier M. Staphylococcus aureus and food poisoning. Genetics and Molecular Research. 2003; 2(1):63-76.

9. Champoux JJ, Neidhardt, Frederick C, Drew W. Lawrence, Plorde, James J, Sherris medical microbilogy. Edisi ke-4. United State of America: The Mc Graw-Hill Companies, Inc.; 2004.

10. Bhat R, Prajna PS, Menezez, Vinita Preethi, Shetty, Pavithra. antimicrobial activities of soap and detergents. Advanced in
Bioresearch. 2011; 2(2):52-62.

11. World Health Organization. WHO guidelines on hand hygiene in health care: first global patient safety challenge clean care is safer care. France: WHO Press; 2009.

12. Brooks GF, Butel JS, Morse SA. Jawetz, Melnick, \& Adelberg's medical microbiology. Edisi ke-25. United State of America: The McGraw-Hill Companies, Inc; 2010.

13. Irianto K. Mikrobiologi menguak dunia mikroorganisme. Jilid 1. Bandung: Yrama Widya; 2006.

14. Putra IA. Uji efek antibakteri ekstrak etanol kulit batang salam \{syzygium polyanthum (weight) walp. $\quad$ terhadap staphylococcus aureus dan escherichia coli secara in vitro (skripsi). Padang: Universitas Andalas; 2013.

15. The Microbial World. The cell wall surrounds and holds in the microbe. 2014 (diunduh 7 Januari 2014). Tersedia dari: URL: HYPERLINK http://www.microbiologytext. com/index.php?module=Book\&func=displaya rticle\&art id=60.

16. Aliyu MS, Tijjani MB, Doko MHI, Garba I, Ibrahim MM, Abdulkadir SM, et al. Antimicrobial activity of sabulun solo a local traditional medicated soap. Nigerian Journal of Basic and Applied Science. 2012;20(1): 35-8. 